\title{
Factors of International Migration of Haitians to the Dominican Republic in 2010-2015
}

\author{
Crispin Magige Ryakitimbo \\ Department of Sociology, School of Public Administration Hohai University, Nanjing, China
}

\author{
Babul Hossain
}

Department of Sociology, School of Public Administration Hohai University, Nanjing, China

Received: October 8, 2019 Accepted: November 13, 2019 Published: November 16, 2019

doi:10.5296/ijgs.v3i1.15841 URL: https://doi.org/10.5296/ijgs.v3i1.15841

\begin{abstract}
The problem regarding migrants has occurred a long time ago in the Dominican Republic where Haitian migrants entered as slaves to the sugar industry in 1990 without certain conditions. The problem is further complicated when the flow of migration from Haiti to Dominica issues a policy to tackle the migration problem with the aim of reducing the high flow of migrants from Haiti. This paper examines the push and pulling factors of the Haitian population to migrate to the Republic of Dominica through the concept of the International Migration and Pulling Factors. Through the National Regularization Plan policy of the government of the Republic of Dominica seeks to reduce the flow of migration from Haiti, however this policy has been less effective since it was implemented in 2015.
\end{abstract}

Keywords: International migration, Dominican republic, Haitian migrants, Push and pull factors of international migration

\section{Introduction}

International migration is the process by which millions of people migrate and move on a global scale across social and geographical scales (Hatton \& Williamson, 2002). While migrants are those who migrate by moving from one place to another where economic growth is higher when compared to the place of origin, which is also referred to as a pull factor. On the other hand the motivating factors for migrants to migrate can be due to poverty, lack of employment opportunities, lack of land due to population-laden settlements, as well as personal basic reasons for migrants to get a better future in the destination country (Richardson, 1989). The policies of the governments of origin and destination countries can act as a stimulus for migration. On January 12, 2010, a massive 7.0 magnitude earthquake struck Haiti near the capital city of Port-au-Prince, causing much of Haiti's agriculture and 
industry to be destroyed and subsequently increasing unemployment rates (University of North Carolina, 2013). This earthquake disaster caused 222,570 people died and 300,572 people were injured, the total value of damage and losses estimated at US \$ 7.8 billion, with economic losses of around 120 percent of 2009 gross domestic product (GDP) in Haiti (Global Issues, 2010) . Faced with a high level of unemployment after the earthquake, there are also other serious problems, cases of corruption and the government's failure to reduce poverty under the administration of President Michel Maetelly in 2012 (BBC News, 2013). These three reasons make the condition of Haiti unstable, so that it helps Haitians to migrate from their country. Haitian migration has actually taken place since the Haitian revolution (1791-1804), where the tens of thousands of people moved into the Caribbean. Economic and voluntary migration has become a hallmark of Haitians, migrating to seek a better life (Ferguson, 2003).

The complexity of migration from Haiti often triggers immigration problems in the destination country regarding the status of the migrants considering that Haitian migrants come and go as economic migrants or as refugees (Audebert, 2017). The purpose of their migration one of which is the Dominican Republic which is a neighboring country. The flow of international migration from Haiti to the Dominican Republic is a type of economic and voluntary migration (Ferguson, 2003). The Inter-American Commission on Human Rights (IACHR) in 1999 noted there were 500,000-700,000 Haitians both from Haiti and Haitian-Dominican descent who had lived and worked in the Dominican Republic (Human Right Watch, 2002), and only 4,000 had visas and complete documents for being in Dominican Republic. As happened at the beginning of the 19th century, where the government of the Dominican Republic lacked workers for sugar production which is one of the most thriving businesses in the Dominican Republic (Richardson, 1989). Since the beginning Haitian migrants have not been treated well, for example in 1937 Rafael Trujillo who was the president of the Dominican Republic at that time launched the anti-migrant Haitian movement and carried out mass killings of Haitian migrants. As many as 15,000 migrants were killed by military forces of the Dominican Republic (Ferguson, 2003).

Related to the presence of migrants from Haiti at this time, in 2010, the constitution of the Dominican Republic issued a policy related to citizenship status in the Dominican Republic. However, this policy does not necessarily become good news for migrants from Haiti domiciled in the Dominican Republic, many migrants remain denied citizenship from the Dominican Republic even though they have long been domiciled there, their unclear identification is their threat to be deported (Inter Press Service, 2007). From this incident, the government of the Dominican Republic came under international pressure from the United Nations and foreign leaders and human rights groups, because there were 200,000 migrants from Haiti who were born in the Dominican Republic without citizenship (Reuters, 2013). The Haitian government says nearly 240,000 migrant workers born outside the Dominican Republic have begun the registration process (The New York Times, 2015). While the Government of the Dominican Republic itself said $90 \%$ of migrants in the country came from Haiti, and in 2014 the government of the Dominican Republic deported migrants who did not have visas and completeness documents to work and live in the Dominican Republic. This policy is called the National Regularization Plan which is a threat to migrants who want to 
enter the Dominican Republic.

After the emergence of the National Regularization Plan in 2013, which was implemented in June 2014 to June 2015, it was effective in giving time for migrants to complete legal requirements and documents to be able to stay in the Dominican Republic, which should reduce the number of migrants coming, instead increasing migrants coming (Foreign Policy, 2016). Since this policy was enacted, out of the 274,000 people who have been deported, the number of Haitian migrants in the Dominican republic has risen to 329,281 (UNDESA, 2015) The high flow of Haitian migrants to the Dominican Republic raises questions about what are the pulling and push factors for migrants to migrate, by understanding these factors, will be compared with the policies of the government of the Dominican Republic.

\section{Literature Review}

\subsection{Push and Pull Factor International Migration}

Migration is a global phenomenon that is not only caused by economic factors but also social, political, economic, cultural, environmental, health, education, and transportation factors (Thet, 2012). This is due to the push factor where there is a lack of opportunity in the socioeconomic situation and also the pull factor in the area which is more developed from the place of origin. The cause of migration flows is inter-regional and intra-regional differences at the macro level and fundamentally the lack of employment opportunities causes sub-standard living conditions (poverty) among socio-economic groups at the micro level. There are three components in population change, mortality, birth rate, migras. The two types of migration, internal migration and international migration. Internal migration is individual migration from one place to another within the scope of one country, while international migration is the migration of individuals from one country to another with the aim of finding work and improving living standards.

Migration occurs due to factors underlying migrants to make the move. There are 'push factors' as well as pull factors that underlie these migrants. According to Thet in his article entitled Push and Pull Factors of Migrations: A Cash Study in the Urban Area of Monywa Township, Myanmar. There is a 'push' factor which is a factor that drives a person with various reasons to leave his place of being to another place, while the 'pulling' factor is a factor that attracts migrants to a place or area. The 'push' factors according to Thet are low productivity, unemployment and no progress, economic conditions of poverty, lack of opportunities to progress and develop. Natural resources do not support and there are natural disasters, and there are no alternatives to increase income. For the pull factors for migrants to come to destination countries such as, there are better job opportunities, high wages, adequate facilities, and more friendly and better working conditions and conditions.

Meanwhile, according to Stanojoska, in the theory of push and pull factors: A New Way Exsplaining the Old "as for the push factors' in migration such as political, social, and economic instability, rapid population growth, high levels of unemployment, poverty, internal conflicts causes civil instability, and factors of violence, instability or oppression by political regimes and unpublished human rights violations from the country of origin so that migrants decide to migrate to the destination country (Petrevski \& Stajonoska, 2012). Whereas the pull factor for migrants to come to the destination country is the opposite of the 'push' factor 
explained earlier. Such as lack of employment in the destination country, a stable and good social environment, a positive economic situation, a democratic system, political stability, a rare background that connects the two (destination countries) and language similarity. In addition to the 'push' and 'pull' factors, according to Stanojoska, there are factors that facilitate the migration, namely the globalization of markets and workers, modernization of the travel system that connects to reduce travel costs, technological factors and the drive to do international migration.

Migration is broadly defined as a change in residence (permanent) both permanently and permanently. There is no limit in changes to the movements made both the distance of movement and the nature of the movement, voluntary, involuntary, or under certain conditions (Lee, 1966). Migration in changes and movements carried out, including origin (destination), destiasion (destination), set of obtacles (some obstacles), and also some factors (personal factors) faced by the migrant. There are 4 (four) main factors in migration as stated by Everett S. Lee;

a. Factors relating to the area of origin

Factors that become an impetus for individuals and groups in moving to destination areas such as;

- Low wages: The low level of wages in the country of origin is a trigger for migrants to migrate which is the influence of the economic condition of the country of origin which is unstable.

- Political and Civil Conflicts: Conflicts that occur in the area of origin between the government and civil can not be avoided, the differences in perception and bureaucracy that are not transparent makes the reason for migrants to migrate.

- Limited opportunities to enter the Labor Market: Limited opportunities in this case are conditions where the state cannot properly meet the primary needs of its citizens, such as access to enter the labor market due to economic instability in the country of origin.

- Family: Family factors here trigger migration because individuals who have families who are in the destination country of migrants, one of the reasons for them to migrate is to gather with their families who have migrated first in order to improve their lives.

b. Factors relating to the destination / place

Factors that attract migrants to migrate to the destination, such as;

- High Wages: The high wage factor is an attraction for migrants to come. The high wages can be attributed to the economic stability in the destination areas, which can be seen from how high the state income and income per capita.

- More Job Opportunities: Job opportunities in destination countries are a trigger for migrants to come and migrate. Job opportunities in destination countries require a large number of workers in various sectors whose sectors are the cornerstone of the economy of the destination country.

- Education: The education system in the destination country is also a consideration for migrants to migrate. The better the system and level of education offered, the attraction for 
migrants to move there and study there, not only from the system that is seen, but also the infrastructure and facilities offered are also their consideration.

c. Obstacles / Barriers Faced by Migrants

In the transfer process, there are a series of obstacles and interventions from the things that hinder the movement itself, such as;

- Lack of Funding: Lack of funds for migrants to travel makes migrants who will migrate consider the travel costs needed in the process.

- Distance: The distance of the destination country of migration and the country of origin becomes a consideration after determining how much it will cost for their trip. The farther the distance will affect the funds needed in the trip.

- Fear: There is a sense of fear in migrants who will migrate through considerations other than the issue of cost and distance traveled as previously explained, they also consider what they are doing in the destination country, how they survive, and type of work what they will do there is their consideration before deciding to leave.

- Physical barriers: Physical barriers that are common in migrants who migrate are the issue of official documents and cultural background in the destination country as their consideration for migrating. They tend to migrate to destination countries that have similar backgrounds to their home countries.

d. Personal factors according to Lee can be another determining factor in the migration process from the place of origin to the destination. This personal factor is an individual perception of the 'push' and 'pulling' factors that influence actual migration. Lee categorizes individual perceptions in the form of pluses and minuses, where pluses are 'attractors' and minuses as 'drivers'. There is a zero (zero) as a counterweight in both. To determine personal factors in this case can be determined through:

- Age: Age consideration in this personal factor relates to the productive and non-productive age of migrants who will migrate whether it is included in the productive age needed in the destination country.

- Gender: Gender becomes important for the destination country to clarify migrants who will work according to the sex and occupation they will work on.

- Race: Race of ethnicity is included in personal factors as a determining factor whether migrants will migrate to destination countries that have the same cultural race as them or not. Aside from the destination country, what are their perceptions of migrants who have the same or different races as they are.

- Education: Educational factors are important for migrants who will migrate to find employment in the destination country. Their abilities and skills will be needed in sectors that will require workers. For that they need to prepare their abilities and skills to get a job in the destination country later.

These factors are the main factors in the occurrence of migration. Both groups and individuals who migrate naturally have their own reasons for migrating. There are factors that encourage migrants to migrate. Vice versa, there are factors that become migrants to migrate to the destination region / country. This is mentioned in the first and second factors that have 
been described previously, where the first factor is related to the country / destination, this is one of the pullers / attractiveness of migrants to migrate to destination countries. Next is the description through the diagram.

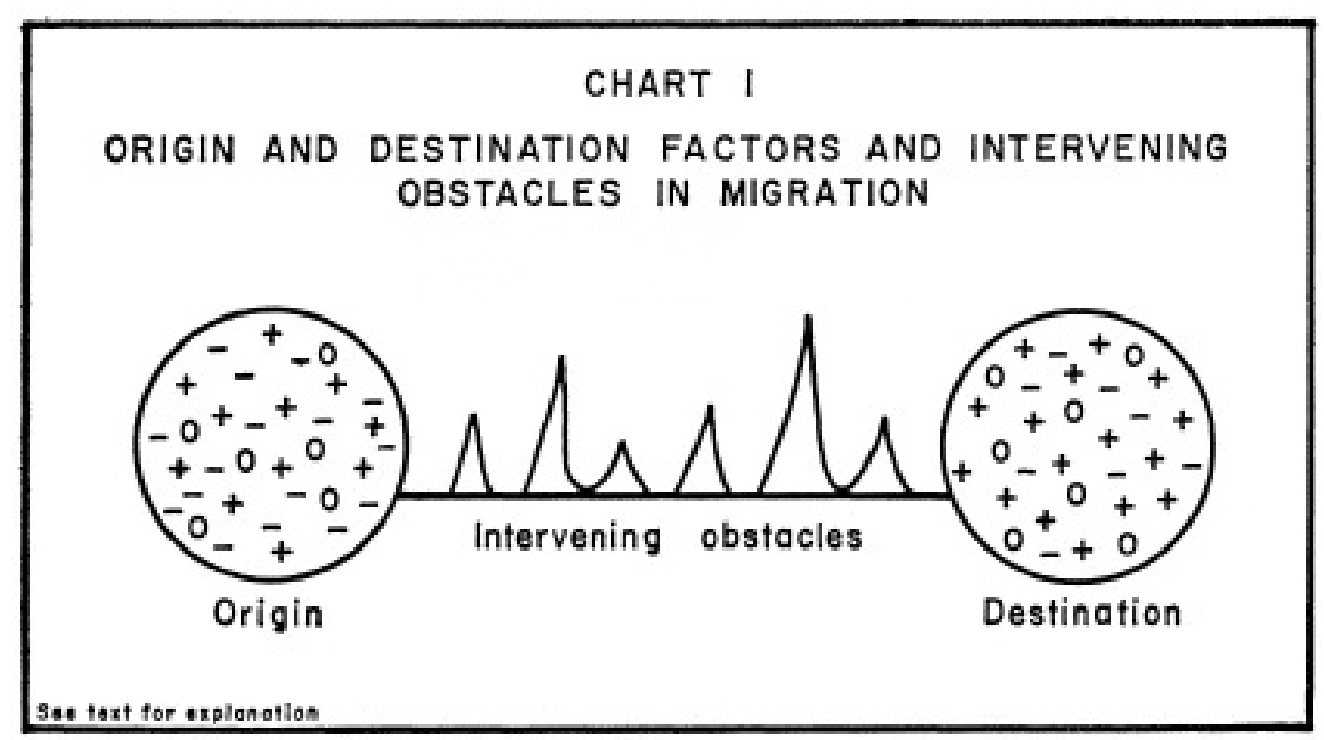

Figure 1. Diagram of Push and Pull Factor of Migration by Everett S. Lee (1966)

In the diagram, there is a plus (+) which is an attraction for people who are in the place, while conversely, minus signs (-) are things that are not an attraction, something that becomes a drawback of the area. For the zero sign (0) are people who have a different view of the others about their residence and are not affected by the conditions there both from the plus and minus sides of the area. This can happen because they have different views and also have an attachment to the area because it is their place of origin so they can understand what is happening there both the bad side and the good side. As for intervening obstacles connecting origin (destination area) and destination (destination area) are obstacles or obstacles faced by people who will make the move from the origin to the destination.

\section{Research Methods}

This type of research is a type of descriptive research. Namely research with the aim of outlining, explaining systematically and accurately about the phenomena and issues concerning the push and pull factor of international migration conducted by migrants from Haiti heading to the Republic of Dominika which led to the issuance of the National Regularization Plan policy by the government of the Republic of Dominika in 2014 towards high migration flows from Haiti to the Dominican Republic.

\section{Discussion}

\subsection{Push and Pull Factors of Migration from Haiti to the Dominican Republic}

Push and pull factors international migration from Haiti to the Dominican Republic are divided into 4 parts namely; origin factors, destination factors, personal factors, and interfening obstacles from Haitian migrants that encourage migration to the Dominican Republic. These four variables will be described as follows: 
1. The push factor of the country of origin

a. Low Wages

The economy is the main focal point for policy makers seeking to improve living standards. In 2002, Haiti had a double economy in which the agricultural sector accounted for $27.1 \%$ of GDP and accounted for around $50 \%$ for employment, while the industrial sector accounted for $16.3 \%$ of GDP, but only contributed about $10 \%$ for the availability employment. Availability of employment opportunities for workers is very important. In the Haitian economy, the agricultural and non-agricultural sectors play an important role in contributing to GDP as well as providing employment for workers. The labor market in Haiti is divided into 2 parts: one for men and one for women. Most male workers work in agriculture. In the agricultural sector only a few women are employed. In contrast, most female workers work in the service sector, but only a small number of male workers are in the service sector.

The labor market plays an important role in improving livelihoods and reducing poverty in Haiti. Employment is very important to lift poor families out of poverty. The growth of the Haitian population is affecting the labor market. Population growth in the previous decade has resulted in a supply that is largely dominated by unskilled labor. As a result, wage levels remain low except for a few skilled and highly educated workers employed, for example in the banking sector, car handling, or medicine

The influence of the agricultural and industrial sectors on the supply of labor in the labor market where labor is dominated by unskilled labor, this has caused unstable wage levels in Haiti. Especially after Haiti was struck by a natural disaster in 2010 the agricultural sector in Haiti has been paralyzed for some time. While $50 \%$ of jobs available in Haiti come from the agricultural sector. To measure wage rates in Haiti due to economic instability before and after the earthquake in Haiti, it can be seen through the figures of gross domestic product (GDP) and per capita income at vulnerable times between 1990-2016. In 1990 Haiti had a GDP of $\$ 3.4$ billion while in 2016 it was $\$ 8.02$ billion. This figure is the highest compared to the previous year where Haiti was at the lowest rate in 1990 of $\$ 3.47$ billion. Based on the following sectors: domestic workers, technicians, bank employees, and other professions in the garment industry, minimum wage standards vary. There are two different standards for minimum wages: the minimum daily wage standard for working in the germen industry of 225 gourdes (US \$ 5.71) and the hourly minimum wage standard tailored to each sector of 300 gourdes (US \$ 7.61) with a minimum count of 8 hours per day.

This is in line with what was conveyed by the Minister of Social Affairs and Employment of Haiti, Joseph Gauthir in early September 2012 at a meeting with representatives from the business sector to discuss the minimum wage. Gauthir stated that the minimum daily wage received by workers in Haiti was at least 300 gourdes (US \$ 7.61).

b. Political and Civil Conflict in Haiti in 2011

One example of corruption cases in Haiti occurred during the reign of President Michel Martelly in 2011 there are indications of corruption in the Martelly government in construction projects that have been invested by construction businessmen from the Dominican Republic, Felix Bautista in the project from a total contract worth \$ 200 million, President Martelly received \$ 2.6 million in funds used for campaign funds in the 2011 presidential election. 


\section{Macrothink}

The emergence of President Martelly's corruption case came to the forefront, prompting Haitian people to rally to demand that the President step down from his position. Participants in the demonstration blocked a dense road in the middle of the city, Port-au-prince. The demonstration by the demonstrators demanded that Martelly step down from the presidency. In addition to demanding Martelly to step down from the presidency, the demonstrators expressed their disappointment at the Martelly government for not being able to hold regional elections in 2011.

c. Limited Opportunities for Haitians to enter the Labor Market in Haiti

Referring to the position of Haiti surrounded by rivers, the agricultural sector in Haiti is vulnerable to hurricanes and tropical storms. In addition, coupled with poor environmental conditions contribute to the high chances of the environment to be affected by natural disasters such as floods and drought. In 2008, yields in Haiti were severely damaged due to a storm attack that occurred with an estimated loss of $\$ 200$ million.

Then in 2010, Haiti was hit by an earthquake measuring 7 on the Richter scale which resulted in damage to agricultural land estimated at $\$ 31$ million. Weak public and private investment in agricultural infrastructure leads to a lack of preventive strategies to minimize the risks and consequences of natural disasters. Such as the lack of protection of irrigation limits that cause flooding and drought as well as lack of funding from the government for preparedness in response to natural disasters.

d. Family

The family factor is another determining factor that drives migrants to migrate to the destination country in this case to the Dominican Republic. Migrants from Haiti who migrate to the Dominican Republic are dominated by Haitians who aim to find work and decent livelihoods. Research conducted by the author, found no family factors in the migration of Haitians to the Dominican Republic.

2. Destination Pull Factor

a. High Wages

Minimum wage standards in the Dominican Republic during 2010-2015 as presented in the data in the following table:

Table 1. Minimum standards for the Dominican Republic

\begin{tabular}{llllll}
\hline Year & $\begin{array}{l}\text { Currency Exchange of the Dominican } \\
\text { (Dominican Peso) }\end{array}$ & $\begin{array}{l}\text { Republic } \\
\text { Exchange } \\
\text { (USD) }\end{array}$ & Rate \\
\hline 2013 & $6,880.0$ & & $170.9 \$$ \\
2012 & $6,035.0$ & $155.9 \$$ \\
2011 & $6,035.0$ & $161.3 \$$ \\
2010 & $5,158.0$ & $143.1 \$$ \\
\hline
\end{tabular}

Sources: country Economy.com 


\section{Macrothink}

From the table data above, if the minimum wage standard in Haiti as previously explained is the driving factor of 300 Gourdes (US \$ 7.61), while in the Dominican Republic RD \$ 6,880 in 2013 , thus it can be concluded that the minimum wage standard in the Republic Dominica is far higher than the minimum wage standard in Haiti.

b. More job opportunities

In immigrant labor in the Dominican Republic there are several movements between several sectors that are dominated by workers from Haitian immigrants. As in the sugar industry sector as a sugar cane cutter. The agricultural sector as laborers harvest agricultural products, as well as in the construction sector. Migrants from Haiti who go migrate to the Dominican Republic with the aim of finding better job opportunities, most of them working in the construction sector. The high demand for labor in the construction sector is due to the large number of buildings such as apartments and office buildings on open land in the Dominican Republic, especially in the capital city of Santo Domingo. Construction of many construction took place in the center of the Dominican Republic in order to build public and public facilities such as supermarkets, malls to schools, and universities.

The massive construction in the center of Santo Domingo is opening up employment opportunities for migrants in Haiti. Development in the city center is centered on residential building projects by $45 \%$, national standard buildings such as government buildings by $19 \%$, buildings for tourist destinations for foreign and local tourists by $13 \%$ and commercial buildings by $9 \%$.

c. Education

Education is one of the pull factors for migrants in Haiti to come to the Dominican Republic. These migrants seek to get a better education in the Dominican Republic. The reason for the migration is to continue education. But in my research education was not found as one of the factors driving migration from Haiti to Dominican Republic.

\section{Personal Factors of Haitian Immigrants}

Personal factors are another determining factor besides the driving and pulling factors for the Haitian population to migrate to the Dominican Republic. These factors include age, sex, race, fear (fear of the perception of the destination country) and the education of the Haitian population who will migrate. The decision to migrate can be based on the age of the prospective migrant whether in the productive age or non-productive age. In Haiti, productive age 15-24 years: $21.25 \%$ (men 1,132,386 / women 1,129,844); 25-45 years: $36.78 \%$ (men 1,943,683 / women 1,972,347); 55-64 years: 5.01\% (men 254,352 / women 279,431). Seen from the translation the majority of productive ages in Haiti are at the age of 25-54 years. This can be a stimulus for the Haitian population to migrate to the Dominican Republic to look for employment opportunities there. Job opportunities in Haiti as explained earlier above, are mostly in construction work and the sugar industry. So job opportunities for Haitian migrants are more dominated by male migrants. Besides Haiti in productive age, more men than women. While based on ethnicity and race, although the majority of $95 \%$ of blacks are of African race and the Dominican Republic is a majority of mixed race $73 \%$ of European-African descent and $16 \%$ of whites and $11 \%$ of blacks, but because of their same historical factors racial factors are not a consideration for Haitian migrants. For the education factor because the majority of 
Haitians who do not migrate to the Dominican Republic work in the informal sector which does not require education or special expertise, the education factor is not a consideration for Haitians to migrate to the Dominican Republic.

\subsection{Constraints Faced by Haitian Immigrants in International Migration to the Dominican Republic}

Haitian migrants who migrate to the Dominican Republic face particular obstacles in the form of physical obstacles in the absence of legal documents and shipping procedures that are set based on Haitian government regulations. So many of the migrants from Haiti were deported to return to their home countries. In addition to physical barriers faced, migrants from Haiti also face fear of the existence of the antihaitianismo attitude displayed by Haiti to Dominica. Antihaitinismo arose because Dominican Republic leaders revived memories of Haitian violence against the Dominican population during the occupation of Saint Domino. In addition, during the occupation the Haitians severed the relationship of the Roman Catholic church in Dominica with the Vatican church. The existence of antihaitianismo is not just past news which has no truth in fact. There was one case where a perpetrator from the Dominican Republic committed acts of violence against Haititan migrants without a clear and definite cause. The incident was witnessed by a citizen of the Dominican Republic who lives next door to a Haitian who was suddenly wounded with a sharp weapon. Not only that, the perpetrators also entered the residence and destroyed the items inside. This has led to fears of its own and also a deep trauma to the Haitian victim because of the sudden attack and only carried out against those who were Haitians. After the incident, 300 Hearts in the environment decided to leave the environment.

Not only with the incident, the Dominican Republic's discrimination against Haitian migrants can be seen from the treatment of those who treat Haitian migrants as residents who are not considered to be there. In 2008, Juliana Deguis, a person who was born in the Dominican Republic but who had parents who came from Haiti, her identity was rejected because of the reason that the last name Deguis sounded very Haitian at all. So in the general election, Juliana could not participate in the general election, this was because Juliana's status was not considered to be included in the category of population of the Dominican Republic and also because Juliana's parents were immigrants from Haiti where they did not get residence status because they were from Haiti.

From the population problems described above about how Julia Deguis experienced discrimination by the Dominican Republic by not recognizing her population status because she came from Haiti and is a descendant of Haiti, it can be seen from the attitude of antihaitianismo that is not just a discourse but it does occur in the Dominican Republic. In 2013, the constitutional court retroactively gave a citizenship clause to all people born in 1929. In a short time, the court revoked and removed the nationality of thousands of Haitians born in the Dominican Republic with parents who were from Haiti. Outside the legal process related to the identity and status of citizenship, a political statement emerged that there were issues regarding antihaitianismo. It is this Antihiatianismo which is compiled as the basis of the Dominican Republic carrying out a politics of hatred, discrimination, against Haitian migrants. 
4.3 Dominican Republic's National Regularization Plan Policy

On September 23, 2013, the constitutional court of the Dominican Republic ruled that Juliana Deguis Pierre, who was born in the Dominican Republic to Haitian parents in 1984 and registered as a Dominican at her birth as permitted by applicable Dominican law at the time, had to be denied Dominic citizenship. due to the migration status of his parents. The decision is in direct contradiction with the binding international obligations of the Dominican Republic per Inter-American Court of 2005. The Dominican Republic states that they neither recognize nor provide opportunities for registration of civilian Dominican citizenship for migrants or residents residing in Dominica but have nationality from Haiti. This was then followed up by the Constitutional Court who appointed the Central Election Council to provide all birth registrations in the Dominican Republic as of 1929 that were allegedly registered incorrectly and identified denationalization by the government of the Dominican Republic against Haitians. This was done because of a statement from the Dominican Republic that also did not recognize all Haitians who were there and their descendants and also indirectly violated the right to citizenship and equality before Haitian law. The Dominican Republic also does not give Haitians the opportunity to register civilally about their citizenship status. From this case, it can be seen that the Dominican Republic discriminates against Haitian migrants there.

From the discrimination against migrant identity in Haiti, the Minister of Internal Affairs and Police of the Dominican Republic, Jos Ramon Fadul reported that the Dominican Republic will implement a new policy to address the issue of citizenship status for foreign migrants from outside the Dominican Republic including Haiti, one of them. The policy is the National Regularization Plan. The basis of the formation of the National Regularization Plan is the Constitution of the Dominican Republic in 2010 which in the constitution has explained that the constitution of the Dominican Republic has accepted and recognized the status of Dominican nationals illegally (in this case Haitian migrants included in foreign citizens who entered illegally into the Dominican Republic ). For the National Regularization Plan policy, it has been explained in it that the High Court of the Dominican Republic revoked the citizenship status of foreign residents in Dominica who came from foreign workers or foreign migrants who entered Dominica illegally who came from Haiti, one of them. This applies to the struggle from 1929 to the subsequent births of the birth of the next generation of migrants to their final offspring in the Dominican Republic.

The Dominican government gives details of the National Regularization Plan for foreign nationals or foreign migrant workers from outside the Dominican Republic. The court's decision retroactively rejected and revoked Dominican citizenship status for anyone born after 1929 who did not have at least one Dominican parent, on the grounds of a constitutional clause stating that all others were in the country illegally or were "on the way" and did not remain permanently in the Dominican Republic until the end in their view. The naturalization plan, outlined in 39 articles listed in the presidential decree, created several different migration categories, including permanent and temporary residents. It takes into account parents with children born in this country, notions of Spanish, education, property ownership, employment, finance, and written and oral criminal history.

The application of these regulations for foreigners / foreign migrants is carried out 
comprehensively in every national territory in the Dominican Republic. From the statement of the Minister of Home Affairs and the Dominican Republic police, the National Regularization Plan policy was implemented aimed at regulating the high flow of migration from outside the Dominican Republic illegally, regulating the immigration status of migrants who came to the Dominican Republic by registering and completing the documents that were provided. in offices appointed by the government to handle administrative and registration matters of foreign migrants who enter illegally and do not have complete legal documents. In addition, it was also stated that in order to achieve the Regularization of its immigration status, the interested parties must have the identification of the country of origin, but if he does not, he can start the process and have 12 months to obtain and complete it. This is intended to provide and clarify the status of migrants who come to Haiti who enter illegally in order to get a clear status and get facilities from the Dominican Republic so that they are not threatened with deportation from the Dominican Republic. The implementation of the National Regularization Plan policy will make it possible for foreigners and migrants living in the country to get regular immigration status accepted legally and legally by the Dominican Republic.

\subsection{Push and Pull Factor International Migration of Haitians to the Dominican Republic in 2010-2015}

In the section on the push and pull factors of international migration that have been outlined in the literature review, there are driving factors of the Haitian population with variables of low wages, political and civil conflicts, limited opportunities to enter the labor market and families. From these drivers through research conducted by the authors based on data collected, effective driving factors driving the migration of Haitians to the Dominican Republic are low wages, political and civil conflicts, and limited opportunities to enter the labor market in Haiti. On the factor of attracting migrants from Haiti into the Dominican Republic, among others; high wages, more employment opportunities, and education. But from the results of research conducted by the author through data collected, only up to wages, and more job opportunities which become attractive factors for migrants from Haiti to come to the Dominican Republic. As for personal factors such as age, sex, race, and level of education, which influence migration from Haiti to the Dominican Republic from personal factors are found in age, sex and race where this can be seen from the data collected by the author and previously described. The obstacles faced by the variable lack of funding, distance, fear and physical barriers, in the case of Haitian migrants only fear and physical barriers that become obstacles for migrants to migrate to the Dominican Republic.

The link between the driving factors and the pull of international migration from Haiti to the Dominican Republic with the Dominican Republic's government policy, namely the National Regularization Plan, can be seen from the policy that was issued when it was implemented, the Dominican Republic government deported migrants from Haiti. Most cases of migrant deportation by the government of the Dominican Republic are migrants from Haiti. This raises the question of why only migrants from Haiti are deported on a large scale. Through research conducted by the author, it was found that the number of migrants from Haiti is very large compared to migrants from other countries and the majority entered the Dominican Republic illegally. For this reason, the government of the Dominican Republic deported until 
it finally issued a policy. The National Regularization Plan policy was issued and demonstrated not only to Haitian migrants but also other foreign nationals in the Dominican Republic but illegally entered. The existence of this policy is to reduce the rate of migration from Haiti to the Dominican Republic to register in order to obtain citizenship status so that the government can provide the appropriate facilities. However, in the case of migrants from Haiti, the study found that in the citation of the policy article one of them is Haitian migrants who were migrants from Haiti who had been in 1929 or were born that year in the Dominican Republic and had parents who were from Dominican Republic. must register to get citizenship status. This shows that before this policy was issued, the citizenship status of migrants from Haiti and Dominican-Haitian descent did not have a clear status in the Dominican Republic.

Despite the technical issues regarding the registration of legal and legal immigration documents shown for migrants from Haiti, returning to the original purpose of this policy was issued and applied to address the problem of high migration flows, especially from Haiti. After the National Regularization Plan policy was implemented in 2014, as many as 80,000 migrants from Haiti were deported from 200,000 migrants who did not have clear citizenship status because of illegal entry. While the rest have been in the process of registering for citizenship status in the Dominican Republic. Then in the following year, in 2015, after the National Regularization Plan policy was implemented, the flow of migration from Haiti to the Dominican Republic did not decrease. Although deportation had been carried out in the previous year, it did not discourage Haitian migrants from migrating to the Dominican Republic. In 2015, according to data compiled by the author through the official website of international migration, 329,281 migrants entered the Dominican Republic from Haiti (World Migration, 2015).

The National Regularization Plan policy issued by the government of the Dominican Republic which was implemented to suppress the flow of migration from Haiti was not particularly effective in overcoming the problem of migration. This is not evident from the registration problems and the legal and legal requirements for completing the documents required by migrant migrants, especially from Haiti to enter the Dominican Republic. However, the ineffectiveness of implementing the policy is found in the migrants. The driving and pulling factors of the Haitian migrants to continue migrating to the Dominican Republic are caused by one of the factors of wage rates and job opportunities. In the Dominican republic development is developing rapidly in downtown Santo Domingo and requires a lot of construction workers to carry out construction there where some of the rough construction workers are foreign migrants mainly from Haiti.

\section{Conclusion}

From this study it can be concluded that the driving factors of Haitian migrants to the Dominican Republic that dominate in the process of international migration are such as the factor of minimum wage differences between Haiti and the Dominican Republic and also the limited employment opportunities in Haiti after the natural disaster occurred in 2010 which resulted in damage to agricultural land where the majority of jobs in Haiti are in the agricultural sector. In addition, problems of government political instability such as corruption and the failure of government regulations to improve the agricultural sector after 


\section{$\triangle$ Macrothink}

the 2010 earthquake caused the migration from Haiti to the Dominican Republic. Besides these factors, there are family factors. The family factor can be seen from the migration flow from Haiti to the Dominican Republic from 1999 to 2002 there were 1.5 million migrants from Haiti who were in the Dominican Republic, which then increased each year due to the high migration flow from Haiti to the Dominican Republic.

The factor of attracting Haitian migrants to the Dominican Republic is dominated by the high minimum wage offered factor as explained earlier about the minimum wage competition in Haiti and the Dominican Republic. In addition, the presence of more employment opportunities in the Dominican Republic due to the high rate of growth that requires a lot of unskilled workers, making migrants mostly work in the construction sector, in the sugar industry sector, the presence of migrant workers is needed. Especially as labor to cut down sugarcane which is the main raw material in the sugar industry. In the tourism sector, the demand for migrant workers is also not small. They are migrant workers who work in the tourism sector, most of the workers as servants in tourist destinations or lodging as cleaning services. Other sectors that also need migrant workers from Haiti are usually employed as laborers in harvesting agricultural products in the Dominican Republic. As for the education factor, in the factor of attracting Haitian migrants to the Dominican Republic, the authors did not find any education factor in this case as an attractor factor is the goal of migrants from Haiti to obtain, pursue, and continue their education better and tiered in the Dominican Republic. However, the fact is, the majority of migrants from Haiti who are in the Dominican Republic do not obtain, pursue or continue their education in the Dominican Republic. This is because migrants are focused on the job opportunities offered where they can work without requiring certain skills to be accepted in jobs in their respective sectors.

Personal factors are decisive for migrants from Haiti to decide to migrate from their home country to the Dominican Republic as their destination country. The age factor of migrants who are included in the productive age, seeing employment opportunities in the Dominican Republic which is dominated in the rough work sector especially construction of buildings makes the majority of migrants who come to the Dominican Republic are men. The majority of job opportunities in the Dominican Republic are in the construction sector where migrant workers do not need skills or certain skills and education to be able to work there because migrants from Haiti are mostly employed as construction workers and other unskilled workers. The existence of the same historical background between Haiti and the Dominican Republic makes migrants from Haiti not too consider the racial and ethnic issues in the destination country.

Constraints faced in the process of migration from Haiti to the Dominican Republic did not impede the funding problem and the distance issue. This is because the distance between the Dominican Republic and Haiti which is next to each other shortens the distance of migrants and also cuts their travel costs. For that both are not a significant problem in the process. However, another obstacle hampering migrants' migration from Haiti to the Dominican Republic is the problem of legality of documents to enter the Dominican Republic which prevents migrants from entering there. This is related to the policy of the government of the Dominican Republic through the National Regularization Plan which was shown to limit the high flow of migration from Haiti to the Dominican Republic. Most migrants from Haiti enter 
the Dominican Republic through border lines and without complete legal and legal documents. So that the government of the Dominican Republic issued a policy to regulate and overcome the problem of the high flow of migrants entering, especially from Haiti. In addition to the issue of completeness of the document, there are other problems that make the Haitian government must continue to dispute with migrants from Haiti even though their existence as migrant workers with low wages is so beneficial for the Dominican Republic, the emergence of antihaitianismo. Antihaitianismo is a political hatred of the people of the Dominican Republic against migrants from Haiti and descendants from Haiti. This Antihaitianismo emerged since the period of Haitian occupation in the Dominican Republic for 30 years with the harsh and unfavorable treatment given by Haiti to the people of the Dominican Republic at that time. During his occupation in Santo Domingo, Haiti severed the relationship of the Roman Catholic church in Dominican Republic with the Vatican church. Antihaitianismo was exacerbated during the reign of president Trujillo. Trujillo ordered his military forces to slaughter as many as 1,500 migrants from Haiti who were in the Dominican Republic at that time for no apparent reason and only based on political practices of hatred resulting from the dark history of the Dominican Republic.

\section{References}

Audebert, C. (2017). Recent Geodynamics of Haitian Migration in the Americas: Refugees or Economic Migrants? https://doi.org/10.20947/S0102-3098a0007

BBC News. (2013). Haiti Clashes As Protester Demand President Martelly Resign. http://www.bbc.com/news/world-latin-america-24996116

Central Intelligence Agency. (2017). The World Factbook.

Dominican Republic Government Site. (2017). Immigration Plan.

Ferguson, J. (2003). Migration in the Caribbean: Haiti. The Dominican Republic and Beyond. Minority Rights Group International

Foreign Policy. (2016). It's Really Happening: The Dominican Republic Deporting Its Haitian Residents.

Global Issues. (2010). Evastating Earthquake in January 2010.

Guengant, J. P. (1996). International Migration, Refugee Flows and Human Rights in North America. New York: Center of Migration Studies.

Haiti Libere. (2012). Hair Economy Minimum Wages.

Hatton, T., \& Williamson, J. (2002). What Fundamentals Drive World Migration? Australian National University Discussion Papers, 45, 1-2. https://doi.org/10.3386/w9159

Helen, C. M. (2001). Domineering Republic and Haiti: Country Students (3rd ed). Federal Research Division, Library of Congress.

Human Rights Watch. (2002). Illegal People: Haitians and Dominico-Haitians in the Dominican Republic. New York: Human Rights Watch

Inter Press Service. (2007). Dominikan Republic: Deport Thy (Datk-Skinned) Neighbor. http://www.ipsnews.net/2007/03/Dominikan-republic-deport-thy-darker-skinned-neighbour/

Lawless, R., Murdo, J. M., \&, Christian. (2018). Antonie. Girault, James. A. Ferguson. "Haiti". 


\section{Macrothink}

International Journal of Global Sustainability

ISSN 1937-7924 2019, Vol. 3, No. 1

Lee, E. S. (1966). A Theory of Migration in Demography. Population Association of America. https://doi.org/10.2307/2060063

Library of Congress. (2006). Country Profile: Haiti. https://www.loc.gov/rr/frd/es/profiles/ Haiti.pdf

Ministerio de Interior y Policia. (2014). Ministro Anuncia Incio del Plan de Regulation of Foreigners).

Mulugeta, F. D., \& Themba, N. (2015). Macroeconomic Immigration Determinants: An Analysis of 'Pull' Factors of International Migration to South Africa. African Human Mobility Review, 1, 27-53.

Petrevski, B., \& Stajonoska, A. (2012). Theory of Push and Pull Factors: A New Way Explaining the Old.

Reuters. (2013). Dominate Government Gives Details of Naturalization Plan for 'Foreigners'. Richardson, B. C. (1989). Caribbean Migrations: 1838-1985. In F. W. Knight, \& C. A. Palmer (Eds.), The Modern Caribbean. Chapel Hill: University of North Carolina Press.

Rocha, R. R. (2011). A politica do Brasil para as migracoes internacionais. Contexto Internacional, 33(1), 47-69. https://doi.org/10.1590/S0102-85292011000100003

Sidney, A. Da S. (2013). Brazi, a New Eldorado for Immigrants? The Case of Haitians and The Brazilian Immigration Policy. Urbanities, 3(2).

Sudirman, D. (2002). Became a qualitative researcher, bandung library loyal (p. 51).

Tea Guardian. (2013). Dominate Republic-Haiti History Conflict.

The Heritage Foundation. (2016). Dominican Republic and Haiti.

The National Minimum Wage Increase in Dominican Republic. (2013). https://countryeconomy.com/national-minimum-wage/Dominikan-republic

The New York Times. (2015). Haitian Workers Facing Deportation by Dominic Neightbours. Thet, Kyaing Kyaing. (2012). Push and Pull Factors of Migration: A Case Study in the Urban Area of Mon days Town, Myanmar. Myanmar: Department of Statistics Institute of Economic Monywa.

Ulber, S. (2010). Research methods (pp. 30-41). https://doi.org/10.1260/0957-4565.41.7.28

UNDESA. (2015). Internationa Migrant Stock.

University of North Carolina. (2013). Haiti Earthquake.

Worl Economic From. (2012). Global Competitiveness Report: Dominican Republic.

Worl Economic From. (2012). Global Competitiveness Report: Haiti

World Bank. (2006). Social Resilience and State Fragility in Haiti Social Analysis. Caribean Country Management Unit.

World Development indicators. (2016). Country Profile: Haiti. 


\section{Macrothink}

\section{Copyright Disclaimer}

Copyright for this article is retained by the author(s), with first publication rights granted to the journal.

This is an open-access article distributed under the terms and conditions of the Creative Commons Attribution license (http://creativecommons.org/licenses/by/3.0/). 